\title{
Development of Motorized Stimulation Models Based on Traditional Gobak sodor Game
}

\author{
Fadilatul Fitria, Suparno \\ Yogyakarta State University, Yogyakarta and Indonesia \\ e-mail: fadilatul.fitria2016@student.uny.ac.id
}

\begin{abstract}
This study aims to improve the speed and agility of children aged 5-6 years through a model of motor-based motor stimulation of traditional gobak sodor, because most parents prefer to give their children a gadget to keep their child quiet rather than providing a stimulus in the form of motion, these is where the teacher's role is played. When teacher have to fight the sophistication of the digital world by introducting to traditional game kids. This development research adopted a step from the development model of Borg and Gall. The 10 steps were simplified into 7 development steps that were divided into three main stages: 7: (1) Preliminary Study, (2) Development Stage, and (3) Product Test Stage. Subjects used for the limited trial were 8 children and for an extended trial using 40 children. The technique of data collection instrument is using interview, observation, and questionnaire. The data analysis technique of effectiveness test used is by non-parametric statistical analysis of wilcoxon test. The results of this study were: (1) motor stimulation models developed eligible for use for speed and agility of children aged 5-6 years. This is evidenced from the response results obtained that the products developed into the category of "very good" and (2) model of motor-based stimulation of traditional gobak sodor game that developed effective for use in the speed and agility increase of children aged 5-6 years. This is evidenced by the wilcoxon test in the expanded trial obtained by a child density of $\mathrm{P}=0.000(<0.05)$, so there is a difference in pace of children aged 5-6 years before and after the gobak sodor game. As for agility $\mathrm{P}=0.000(<0.05)$, so there is a difference agility of children aged 5-6 years before and after the game gobak sodor.
\end{abstract}

Keywords: $\quad$ speed, agility, motor stimulation model

\section{INTRODUCTION}

Early Childhood Education is an effort made to educate and develop the potential of early childhood. In accordance with the principle of early childhood learning that the process of early childhood learning is done through play. Playing also as a means of learning children to learn culture in the surrounding environment through a game.

we can categorize the types of games into two types of games namely modern games and traditional games. Today, modern games are ingrained in the environment of early childhood, but smartly we as parents and educators should think about the impact of this modern game. Children who often spend their time using technology such as TV, gadgets, laptops, etc. are often not active in motion or only use their imitation (With \& Child, nd), this is also reported by Rielly et al (2004) that children age 3-5 years tend to spend $76-79 \%$ hours on the monitor screen in a fixed activity. This negative impact is what brings us to "back to nature" which is to choose traditional games to be played by children. Traditional games are games played by children in an area which is a local culture of the area. This traditional game will make children feel happy and earnestly play it (Sukintaka, 1991: 130).

Game activities are designed to improve the motoric aspects of children, especially speed and agility in children aged 5-6 years. Speed is the ability to take a certain distance with a short time (Hidayat, 2014: 61). According to (Sujiono, 2010; 
Gallahue, D \& John, 1998: 282), while agility is an ability to change direction with fast and precise movements that combine elements of speed, flexibility, and coordination (Baley, 1986: 195; Sukadiyanto, 2010). Early physical motor development of children is one of the significant development aspects in children's lives (Wahyudin \& Mubair, 2011: 6)

This can be seen from motoric activities provided by the teacher only morning exercise every Tuesday to Saturday which makes children feel bored with these activities. Then the train enters each class and the child seems to have difficulty when changing the direction of movement of his body in a short time because the development of aspects of speed and agility of the child is still less than optimal. This is due to the lack of children getting the opportunity to practice their motor skills, especially speed and agility. Lack of teacher knowledge in exploring traditional games that can actually help teachers design varied motor learning activities. The maturity of a child who does not get the stimulus so that his speed and agility develop has not been maximized. Lack of stimulus given to children so that children are less motivated to play activities, and there is no traditional game-based learning model

From the observation analysis process, it can be seen that a learning model is needed to help educators stimulate the child's motorbike especially the speed and cunning of the child as a solution to these problems. Based on the background of the problem the researchers intend to develop children's motorics in a study entitled "development of motor stimulation models based on traditional gobak sodor games to increase speed and agility in children aged 5-6 years"

The results of research conducted by researchers found that the motor stimulation model is based on traditional gobak sodor game that is appropriate to increase the speed and agility of children aged 5-6 years.

\section{METHOD}

The procedure for developing motor stimulation models based on traditional gobak sodor games here follows the steps of research by Borg and Gall (1983: 775), which was adopted and simplified into 7 steps with 3 main parts, namely: (1) preliminary study, (2) product development and (3) product trials. In limited trials using 8 children aged
5-6 years. And the trial was expanded using 40 children. Data collection techniques using interviews, questionnaires, and observations. To determine scores and criteria (Mardapi, 2008: 123) scale of four:

\begin{tabular}{ll}
\hline Score interval & Description \\
\hline $\mathrm{X} \geq \bar{X}+1.5 \mathrm{SBx}$ & Very good \\
$\bar{X}+1.5 \mathrm{SBx}>\mathrm{X} \geq \bar{X}$ & Good \\
$\bar{X}>\mathrm{X} \geq \bar{X}-1.5 \mathrm{SBx}$ & Enough \\
$\mathrm{X} \leq \bar{X}-1.5 \mathrm{SBx}$ & Less \\
\hline
\end{tabular}

Information:

$\mathrm{X}^{-}=$average overall score $[1 / 2$ (highest score + lowest score)]

$\mathrm{SBx}=$ standard deviation of overall score $[1 / 6$

(lowest score-lowest score)]

$\mathrm{X}=$ the score achieved

\section{RESULT AND DISCUSSION}

Table 1. Expanded Test Result Data on Motor Stimulation Models Based on Traditional Games Gobak Sodor

\begin{tabular}{lllll}
\hline \multirow{2}{*}{ Result } & \multicolumn{2}{c}{ Speed } & \multicolumn{2}{c}{ Agility } \\
\cline { 2 - 5 } & Pretest & Postest & Pretest & Postest \\
\hline Min & 17.10 & 16.80 & 5.80 & 5.00 \\
Max & 29.40 & 27.50 & 12.00 & 12.00 \\
Mean & 21.67 & 19.08 & 8.08 & 6.51 \\
St. & 2.89 & 2.53 & 1.44 & 1.40 \\
deviasi & & & & \\
\hline
\end{tabular}

Based on the table above, the average speed of the trial was expanded at pretest by 21.67 and after being given treatment with motor stimulation models based on traditional game gobak sodor at 19.08, the standard deviation before the application of the stimulation model was 2.89 and after application was 2.53 .

Whereas for agility is obtained an average of 8.08 after being given treatment with a motor stimulation model based on the traditional game gobak sodor of 6.51 while the standard deviation before application is 1.44 and after application 1.40.

Based on the descriptive statistics of children's motor data, especially speed and agility, it was found that there was a difference in the speed and agility of children using learning by applying motor stimulation models based on traditional gobak sodor games, as follows: 
1. Speed

\begin{tabular}{|c|c|}
\hline \multicolumn{2}{|c|}{ Test Statistics ${ }^{b}$} \\
\hline & $\begin{array}{l}\text { Speed posttest - } \\
\text { Speed pretest } \\
\end{array}$ \\
\hline $\begin{array}{c}\mathrm{Z} \\
\text { Asymp. Sig. (2-tailed) }\end{array}$ & $\begin{array}{r}-5.136^{\mathrm{a}} \\
.000\end{array}$ \\
\hline
\end{tabular}

a. Based on positive ranks.

b. Wilcoxon Signed Ranks Test

$P=0,000(<0,05)$, there is a difference in the speed of children aged 5-6 years before and after the gobak sodor game.

2. Agility

Test Statistics ${ }^{b}$

\begin{tabular}{|c|r|}
\hline & \multicolumn{2}{|c|}{$\begin{array}{c}\text { Agility posttest }- \\
\text { Agility pretest }\end{array}$} \\
\hline $\mathrm{Z}$ & $-5.460^{\mathrm{a}}$ \\
Asymp. Sig. (2-tailed) & .000 \\
\hline
\end{tabular}

a. Based on positive ranks.

b. Wilcoxon Signed Ranks Test

$P=0,000(<0,05)$, there are differences in agility of children aged 5-6 years before and after the game gobak sodor

\section{CONCLUSION}

Based on the above explanation about the results and the discussion that has been stated, conclusions can be drawn about the products that have been produced. Following are the conclusions from this study:

1. Needs Needed in the Learning Process The needs needed in the learning process in kindergarten are: (a) learning that interests children and fun that is packaged in traditional games, (b) learning emphasizes the needs listed in the Level of Achievement of Child Development, especially in the scope of motor development, (c) through gobak sodor traditional games can help increase speed and agility in children aged 5-6 years.

2. Feasibility of Stimulation Models Based on Traditional Games Gobak Sodor This motorized stylulation model based on the traditional gobak sodor game was developed with reference to the steps of R \& D research and development by Borg and Gall and through literature studies motor stimulation models based on traditional games of gobak sodor are suitable for use to increase speed and agility. This is evidenced by the results of the teacher's response to the trial that traditional gamebased motor stimulation models fall into the "very good" category. So it was concluded that the motor stimulation model was based on the traditional game of gobak sodor worthy to increase the speed and agility of children aged 5-6 years.

3. Effectiveness of Stimulation Models Based on Traditional Games Gobak Sodor The motor stimulation model based on the traditional gobak sodor game was declared effective to increase the speed and agility of children aged 5-6 years. The effectiveness can be seen from the results of the Wilcoxon test analysis that has been carried out to children totaling 40 children in ABA III Pare Kindergarten. The results of the effectiveness are evident from the expanded test which shows that $\mathrm{p}$ $<0.05$ is 0.000 . Therefore, it was concluded that the motor stimulation model based on the traditional gobak sodor game could increase the speed and agility of children aged 5-6 years.

\section{REFERENCES}

[1] Baley, James A. (1986). Pedoman Atlet Teknik Peningkatan Ketangkasan dan Stamina. Semarang: Dahara Prise.

[2] Gallahue, David L., \& Ozmun, John C. (1998). Understanding Motor Development Infants, Children, Adolescents, Adult,. Singapore: McGraw-Hill.

[3] Sujiono, Yuliani. (2009). Konsep Dasar Pendidikan Anak Usia Dini. Jakarta: PT Indeks

[4] Sukadiyanto. (2010). Pengantar Teori Dan Metodologi Melatih Fisik. Bandung: CV Lubuk Agung

[5] Sukintaka. (1991). Teori Bermain Untuk PGSD Penjaskes. Jakarta: Depdikbud

[6] Dirjen Pendidikan Tinggi Proyek Pembinaan Tenaga Kependidikan.

[7] Wahyudin, Uyu \& Mubair Agustin. (2011). Penilaian Perkembangan Anak Usia Dini. Bandung: PT Refika Aditama

[8] Anning, A. (2006). Early Years Education: Mixed Messages and Conflicts. In K. Derek, E. Mufti \& J. Robinson (Eds.), Education Studies: Issues and Critical Perspectives (pp. 5-17). New York: Open University Press.

Use this format for journal article

[9] Reilly, J. J., Jackson, D. M., Montgomery, C., Kelly, L. A., Slater, C., Grant, S., \& Paton, J. Y. (2004). Total Energy Expenditure and Physical Activity in Young Scottish Children: Mixed Longitudinal Study, 363,211-212.

[10] With, P., \& Child, Y. (n.d.). The Importane of Play in Early Childhood Development. MSU. 
[11] L.E. Young, Assessment for learning: Embedding and extending, 2005, [online article], retrieved from http://www.ltscotland.org.uk/Images/Assessmen t\%20for\%20Learning\%20version\%202vp_tcm4 -385008.pdf

[12] M. Harris, "Self-assessment" ELT Journal vol. 51, January 1997.

[13] A. Bandura, "Perceived self-efficacy in cognitive development and functioning", Educational Psychologist, 28, issue 2, 1993, pp.117-148.

[14] J.H. McMillan and J. Hearn, Student selfassessment: The key to stronger motivation and higher achievement. Educational Horizon, 2008.

[15] B.J. Zimmerman, "Self-Efficacy: An Essential Motive to Learn", Contemporary Educational Psychology", vol. 25, 2000, pp. 82-91, doi: 10.1006/ceps.1999.1016

[16] L. Earl, Assessment as learning: using classroom assessment to maximise student learning. Thousand Oaks, CA: Corwin Press, 2003

[17] C. Rolheiser and J.A. Ross, "Student selfevaluation: What research says and what practice shows", [online article], retrieved from http://www.cdl.org/resourcelibrary/articles/self_eval.php?type $=$ subject $\&$ id $=$ 4, 2001

[18] M.V. Johnston and R.O. Smith, "Single subject designs: current methodologies and future directions". OTJR: Occupation, Participation, and Health, vol. 30, Winter, 2010, pp. 4-10.

[19] G. Albaum, "The Likert scale revisited: an alternate version", Journal of the Market Research Society vol. 39, issue 2, 1997, pp. 331-348.

[20] R. Garland, "The mid-point on a rating scale: is it desirable?" Marketing Bulletin, vol. 2, May 1991, pp. 66-70.G. Albaum, "The Likert scale revisited: an alternate version", Journal of the Market Research Society vol. 39, isuue 2, 1997, pp.
331-348. 